\title{
Federal enforcement and reduction of deforestation in the Brazilian Amazon
}

David Costa Correia Silva ${ }^{1}$
Marcos Rodrigues ${ }^{2}$

1 Doutor em Desenvolvimento Socioambiental pela Universidade Federal do Pará e graduado em Economia pela Universidade Federal do Pará. Professo na Universidade Federal Rural da Amazônia, campus Paragominas, Brasil.

E-mail: davidcorreiasilva@hotmail.com 19 http://lattes.cnpq.br/1452889785005235 iD http://orcid.org/0000-0001-6061-6665

2 Doutor em Desenvolvimento Socioambiental pela Universidade Federal do Pará e graduado em Administração pela Universidade Estadual de Mato Grosso. Professor na Universidade Federal Rural da Amazônia (UFRA), campus Parauapebas, Brasil.

E-mail: marcos.rodrigues.adm@gmail.com 19 http://lattes.cnpq.br/4645477865203115 iD http://orcid.org/0000-0003-3879-6115

\begin{abstract}
Agricultural activities are considered the main cause of deforestation in the Brazilian Amazon rainforest. Command and control operations of the Brazilian government, fines and monitoring of illegal activities are institutional mechanisms to reduce deforestation in the region, mainly supervising the agricultural activities. The objective of this study is to analyze the effects of agricultural activities on deforestation in the $21^{\text {st }}$ century, considering the role of government and enforcement to reduce deforestation rates in priority municipalities in the Amazon. Using panel data analysis with 335 municipalities of Mato Grosso, Pará, and Rondônia, including high-priority municipalities to combat deforestation, we show that cattle ranching remains the leading cause of deforestation in the Amazon rainforest, while soybean cultivation and others temporary crops do not yet represent a major threat. In addition, it is observed that enforcement operations produce positive effects in reducing deforestation, combating activities not conforming to the legislation and sustainability standards. Although this institutional mechanism of enforcement is reaching its limits, slowing the reduction of deforestation rates in recent years.

Keywords: sustainability; panel data; cattle; soybean; Amazon;
\end{abstract}

RESUMO: As atividades agrícolas são consideradas a principal causa de desmatamento na floresta amazônica brasileira. Operações de comando e controle do governo brasileiro, multas e monitoramento de atividades ilegais são mecanismos institucionais para reduzir o desmatamento na região, principalmente na supervisão das atividades agrícolas. O objetivo deste estudo é analisar os efeitos das atividades agrícolas sobre o desmatamento no século XXI, considerando o papel do governo e da fiscalização para reduzir as taxas de desmatamento em municípios prioritários na Amazônia. Usando a análise de dados em painel com 335 municípios de Mato Grosso, Pará e Rondônia, incluindo municípios de alta prioridade para combater o desmatamento, mostramos que a pecuária continua sendo a principal causa de desmatamento na floresta amazônica, enquanto o cultivo de soja e outras culturas temporárias não ainda representam uma grande ameaça. Além disso, observa-se que as operações de fiscalização produzem efeitos positivos na redução do desmatamento, combatendo atividades não conformes à legislação e aos padrões de sustentabilidade. Embora esse mecanismo institucional de fiscalização esteja atingindo seus limites, diminui a redução das taxas de desmatamento nos últimos anos.

Palavras-chave: Sustentabilidade; dados em painel; agricultura; soja; Amazônia

\section{INTRODUCTION}

The Amazon, the largest forest area on the planet, covers more than 5 million square kilometers over nine Brazilian states. Its size and importance are reflected in the conflict between the preservation of fauna and flora and the continuity of economic activities. The limited capacity of forest resiliency (HIROTA et al., 2011) and the importance of the Amazon for the global environment places a great responsibility on Brazil for the management of native forests. In addition, international demands have led the country to formulate rules 
to ensure the future of the forest. One of the main challenges for countries in the Amazon region is to build a strategy reconciling productive activities and forest preservation.

Contrasting to the current need for environmental preservation is the way in which the region was economically directed by the Brazilian government in the second half of the last century. In particular, the economic development of several Amazon municipalities was linked to deforestation and sequential development of agricultural activities. Among the reasons for deforestation were demographic pressures from other regions of the country, agricultural incentives based on low land prices and interest rates, and government investment and subsidies for agriculture (FEARNSIDE, 2005; KIRBY et al., 2006).

The conservation of the Amazon does not necessarily mean the interruption of economic activities, but rather, their adaptation to the requirements of legislation and pressures that arise in society, which are reflected in market practices. Other mechanisms are strategies to add value to local produce, such as certification or cultural appreciation, reducing environmental impacts by adopting sustainable practices, provision of funding only to those who comply with laws, and use of allowed inputs and licensed pesticides (NEPSTAD; STICKLER; ALMEIDA, 2006).

In this context, the Brazilian government has an important role in the preparation of appropriate legislation to contain deforestation, as well as the command and control operations in the region, constraining illegal practices and ensuring the preservation of the Amazon concomitantly with the performance of agricultural activities. Several studies have analyzed the impact of agricultural activities, policy incentives for the occupation of the Amazon, and the conflict of land ownership and its impact on deforestation (ALDRICH et al., 2012; ARAUJO et al., 2009; FEARNSIDE, 2001; HECHT, 1985;
WALKER; MORAN; ANSELIN, 2000). The present study contributes to the analysis of how the new institutional environment, with the government acting as a principal agent in the Amazon, is able to reduce deforestation and to identifying the limits of the mechanisms developed (HARGRAVE; KISKATOS, 2013; VERBURG et al., 2014).

The purpose of this study is to investigate the relationship between deforestation and the expansion of agricultural activities in the Amazon in the $21^{\text {st }}$ century, considering the effect of public policies and enforcement to combat deforestation on compliance with legislation. Our hypothesis is that soybean cultivation and cattle ranching were the leading causes of deforestation in the Brazilian Amazon in the $21^{\text {st }}$ century, however, public policies to combat illegal deforestation and the role of government in command and control operations have had important results in reducing deforestation in recent years.

\section{OCCUPATION OF THE AMAZON AND INSTITUTIONAL ENVIRON- MENT TO COMBAT DEFORESTA- TION}

Throughout the intense period of colonization of the Amazon during the 1960s-1990s, the Brazilian government formulated policies to encourage the occupation of the region, offering reduced taxes and subsidized credit for the installation of new businesses, especially in the agricultural sector (ANDERSEN; GRANGER, 2007). The timber industry grew as an important economic activity in the region, while cattle ranching followed into the cleared areas to become an extensive activity. With low volume of capital investment per hectare, its purpose was to secure land tenure through economic use, resulting in conflicts that extend to the present (ARAUJO et al., 2009). Regarding the history of deforestation in the Brazilian Amazon, Fearnside (2005) considers that the direction for the region's 
deforestation was determined in the 1970s in the so-called "arc of deforestation," a region that comprises the areas of the states of Rondônia, Mato Grosso, and Pará.

The occupation of the Amazon was initially undertaken through logging as the main economic activity and capital accumulation, with cattle ranching soon after. Ascattle ranching requires little capital, its main task was to ensure the economic occupation of the land for its legalization (ALDRICH et al., 2012).This led to the replacement of native forest areas with pasture. This process was developed and promoted by the institutional environment of that historical period, leading to livestock becoming the main cause of deforestation in the Amazon (MARGULIS, 2003).

In general, the arrival of agriculture occurs only when there is sufficient capital and logistics structure to support agricultural development. In the case of soybeans, its expansion in the Cerrado (tropical savannah) occurred from the 1980s and intensified from the late 1990s. Although agriculture often materializes after other activities in areas that had been cleared already, it can lead to what Fearnside (2001) defines as the dragging effect, which occurs when destructive activities, such as livestock farming, are accelerated over time by the infrastructure installed to facilitate agricultural production, such as soybean. Although soybean and other agricultural cultivation are not the main deforestation activities, they provide conditions for other activities to intensify this process (MORTON et al., 2006).

The construction of roads has been identified as a contributing factor to deforestation (PFAFF et al., 2007). Although not decisive factors, roads create logistical conditions to connect productive areas with consumption centers. Nepstad et al.(2001) demonstrate that highways can further encourage deforestation by stimulating the expansion of agriculture and cattle ranching in the Amazon. In addition, the construction of hydroelectric power plants causes damage to vegetation and while space is required to construct the plant itself.

It is evident that the Brazilian government induced the formation of an institutional environment in which economic activities in the Amazon have become the main causes of deforestation, but these institutions were grounded in development strategies from that historical period. This kind of development led to two interrelated manners of deforestation. The first is an economic source directly linked to production: livestock, agriculture, and mining. The second source is infrastructure, including support activities linked to production, such as highways and hydroelectric plants (TUNDISI et al., 2014).

With regard to the environment, since the second half of the $20^{\text {th }}$ century, several global forums have discussed the impact of humanity on the world environment, as such problems as pollution and climate change have seeped into popular awareness and overtaken academic discussion. The first major global meeting to discuss the environment took place in 1968 in Rome - Club of Rome -,and pointed to issues concerning natural resources, economic growth, pollution, and quality of life(MEADOWS et al., 1972), culminating in a discussion of the relationship between humanity and the environment on a global scale. As deforestation is one of the main forms of environmental aggression, it became one of the first targets for action mentioned at international conferences, and the Rio Summit in Brazil in 1992 dealt with various issues related to forests, such as biodiversity, rational development, legal mechanisms, and other actions to improve supervisory activities directed at forests worldwide.

The change of the Brazilian institutional environment for the Amazon reflects the perceptions of different agents about the importance of the region and its natural resources. Increased social pressure for environmental preservation, trade embargoes on 
non-certified products, agreements at international meetings, new standards of sustainability, among other social movements, has demanded a new attitude of the Brazilian government, which has responded by improving legislation, intensifying command and control operations, and implementing a system of fines for environmental crimes and new mechanisms of governance of the Amazon territory.

In particular, a recent change in environmental legislation involves the new Brazilian Forest Code. Impeding the free exploration of rural properties ${ }^{1}$, the law limits an owner's capacity to maximize economic land use through the total deforestation of an area through agricultural activities or livestock. It aims to identify economic agents that perform illegal activities in the region, often linked to deforestation, such as illegal logging. By punishing such activities, the government makes the option of illegal activities less attractive, thereby increasing control over deforestation in the Amazon.

Alternatives to deforestation have arisen through the creation of governance mechanisms to maintain native forest areas. Protected areas, indigenous parks, and extractive reserves (NOLTE et al., 2013; SCHWARTZMAN; ZIMMERMAN, 2005) are forms of territorial management employed by the Brazilian government with multiple purposes, including reconciling conservation and economic use of the territory. The result of institutional environmental change has been reduced deforestation rates in the $21^{\text {st }}$ century.

\section{METHODOLOGY}

\subsection{Data}

\footnotetext{
${ }^{1}$ The law considers that every rural property located in the Amazon must preserve $80 \%$ of the native vegetation in the form of legal reserve, $35 \%$ for the Cerrado areas, and $20 \%$ for other areas.
}

In this study, we selected as units of analysis 335 municipalities in the states of Mato Grosso (141), Pará (142), and Rondônia (52), using database information between 2001 and 2012. The data of deforestation rates, expressed in square kilometers deforested, were obtained from the Brazilian Space Research Institute (INPE, 2015). Data for the total cultivated area of soybeans and other temporary crops (ha), cattle herds (total), and gross domestic product (GDP) per capita in each municipality were selected by the Brazilian Statistical Office (IBGE, 2015)2. Monetary values were updated to December 2012 prices in Brazilian national currency through the GDP deflator. Priority municipalities to combat deforestation or deforestation monitored and under control were selected from the latest updated list (October 14, 2013) from the Ministério do Meio Ambiente (MME, 2015). Only the municipalities of Mato Grosso, Pará, and Rondônia were considered for the list.

The choice not to use economic variables analyzed for primary products (soybean, meat, and other agricultural crops) results from model specification to explain the effects of expansion or contraction of activity in the Brazilian Amazon. Hargrave and Kis-Katos (HARGRAVE; KIS-KATOS, 2013) use such economic variables in their work, demonstrating the effects of price changes on the rate of deforestation in the Amazon. However, price declines may not necessarily mean decreased activity to stop deforestation, especially in relation to soybeans produced in the Cerrado of municipalities in Mato Grosso. In addition, the soybean production chain was able to develop market institutions contributing to the conservation of the Amazon Biome (GIBBS et al., 2015; RUDORFF et al., 2011). Highly mechanized soybean production requires intensive use of capital, so its profitability is

\footnotetext{
2 Data for soybean crop area, other temporary crops area, cattle herd and GDP were converted into thousand.
} 
achieved through economies of scale, which requires the expansion of arable land and therefore, increases pressure on forest areas, pressing the native forest. Beef prices tend to produce better results on deforestation than soybean prices. The variation of crop area utilized in this study involves an immediate explanation of the behavioral activity in each year with the variation of deforestation.

\subsection{Empirical Approach}

To measure the influence of agricultural and logging activities on deforestation in the Amazon region, data for the $21^{\text {st }}$ century from 335 municipalities were selected for panel data estimation of the following Equation 1.

$$
D E F_{i t}=\alpha_{i}+X_{i t}^{\prime} \beta+D_{i t}^{\prime} \delta+\mu_{i t}
$$

Where $D E F_{i t}$ is the total deforested area from the municipalities ( $i=1,2, \ldots$ 335) over the years analyzed $\left(t=2001,2002, \ldots\right.$ 2012), $\alpha_{i}$ is the constant for each municipality through estimation by panel data with fixed effects, $X^{\prime}$ is the matrix of independent variables, these being the annual crop of soybeans in the cultivated area, the total area for other temporary crops, cattle herd, GDP per capita, and GDP per capita squared. In addition, we added a lagged variable to livestock. $D^{\prime}$ is a matrix of dummy variables, $\beta$ and $\delta$ are the estimated parameters vectors, and $\mu$ is the error term. We proceeded to eliminate individual constant term $\alpha_{i}$ through the estimation of the firstdifference model between the variables (Equation 2), thereby losing one observation per municipality and maintaining the array of dummies variables.

$$
\Delta D E F_{i t}=\Delta X^{I}{ }_{i t} \beta+D^{\prime}{ }_{i t} \delta+\varepsilon_{i t}
$$

In this model, we selected two dummies. $D_{d}$ represents municipalities that had high above-average deforestation, and therefore, determines the main deforester group in the
Amazon, thereby making it possible to verify the most harmful environmental activities. $D_{p}$ represents government enforcement of the main deforestation municipalities, assuming a value of 1 for priority municipalities to combat deforestation in the Amazon from the year that was included is the list until the removal year. A negative value for the parameter is expected, proving that the state's enforcement action on the major municipalities is effective. Dummy variables identify where the existence of government is more representative (priority municipalities), functioning as an institutional variable (GARRETT; LAMBIN; NAYLOR, 2013; JONES; TRUE; BAUMGARTNER, 1997).

Regarding the explanatory variables, it is expected that the coefficient of cattle ranching (variation of cattle herd) is positive, which would confirm the theory that cattle ranching is one of the major activities in the region contributing to deforestation (ALDRICH et al., 2012; WALKER; MORAN; ANSELIN, 2000). We expected the same for soybeans and other temporary crops. To GDP per capita variable, it is expected a positive value, demonstrating that real increase in wealth implies higher use of natural resources, while for GDP per capita squared an expected negative value mean that every increase in wealth has a decreasing scale effect. By the lagged variable for effective bovine, we sought to analyze whether this variable influence on deforestation over time.

The second model was estimated to assess the outcome of municipalities with more significant deforestation. From the initial 335 municipalities, we selected 168 with average annual deforestation of more than $10 \mathrm{~km}^{2}$, maintaining the same variables and dummies for analysis. In this way, it is possible to compare the diffusion of activities and deforestation in the Brazilian Amazon with the region's arc of deforestation. 


\section{RESULTS AND DISCUSSION}

Institutions are structures designed for human interaction and are organized into formal and informal rules. Informal rules exist purely for relationships between agents: norms of behavior, conventions, and rules of conduct. On the other hand, formal rules (i.e., contracts, laws, and constitutions) have a constraining agent, often the government. Institutions are designed to reduce uncertainty and are guides to human interaction (NORTH, 1990). In the Amazon initially, there were institutions that encouraged productive activities that were aggressive to the environment; however, the new institutional framework has changed the trajectory of the use of natural resources. The challenge is to apply institutional theory through the new agenda of the Brazilian government's role in the Amazon rainforest.

The formation of institutions depends on the organization of each society. Such institutions are built in different ways due to cultural heritage and are passed on between generations (NORTH, 1994). However, institutional economics indicates that socioeconomic structures change over time. North (NORTH, 1990) emphasizes that institutional changes are complicated processes, and are usually slow to change with the expectations of agents.

In the second half of the $20^{\text {th }}$ century, there was a change in how humanity viewed the environment generally. It was no longer viewed as a place for economic exploitation or simple preservation of the landscape, and came to be considered from the perspective of invaluable interaction with economic activities. This new perspective has led to an international political dispensation that encourages changes in the trajectories of the uses of natural spaces. Thus, because Brazil is the holder of the planet's largest area covered by native vegetation, it is one of the countries most tar- geted by governments and NGOs pressing for new environmental protection measures to be adopted.

Global forums and international pressure have pressured Brazilian society to accept the importance of combating illegal deforestation, which has intensified especially since the last decade of the $20^{\text {th }}$ century, when the national government began to enforce behavioral change by agents through an institutional plan. The 1992 Rio Summit for the first time clarified the relevance of forests and boosted the debate on sustainable development and the preservation of forests for both biodiversity and cultural diversity (UNITED NATIONS, 1992).

The Rio Summit resulted in Agenda 21, the first document seeking to establish international legal regulations concerning the protection of forests (KUNZMANN, 2008). Even though the proposal failed to be heeded widely, the issue of combating deforestation was adopted. Brazil was initially reticent to join international conservation programs, but gradually began to adopt measures to reduce deforestation and change its productive logic focused on environmental degradation.

The new logic being established in the Amazon is directly opposed to the previous productive arrangement, at least in part, since it has increased the power of supervision while police action has been able to suppress part of the illegal timber harvesting. The proof is in the drop in deforestation rates. However, this approach requires both social action, with the mobilization of advocacy groups focused on preservation and the consciousness of local people about the importance of forests, and government action, which performs the role of constraining individuals, restricting their free uncontrolled exploitation of natural resources by developing efficient legal mechanisms for monitoring, surveillance, and control of illegal deforestation (KUNZMANN, 2008; SCHNEIDER, 2006). In this context, 
the government has the task of developing formal institutions to prevent deforestation in the Amazon when such activities represent a risk, and occasionally of using its ability to prevent the free use of land.

Analyzing deforestation data, the states of Mato Grosso, Pará, and Rondônia hold the largest share of deforestation in the Brazilian Amazon (Figure 1). From 1988 to 2013, they together accounted for $81.5 \%\left(328,106 \mathrm{~km}^{2}\right)$ of the increase in total deforested area in the Amazon (another six states accounted for the remaining 18.5\%). From this perspective, it is clear that the government's performance must be constant for these regions, because the activities that account for most deforestation are concentrated therein. Since 2004, the annual rate of deforestation has been declining every year, and in 2008 with the intensification of state presence to enforce compliance with legislation, this reduction grew significantly.

Figure 1: Deforestation rates in the Brazilian Amazon and main deforestation states

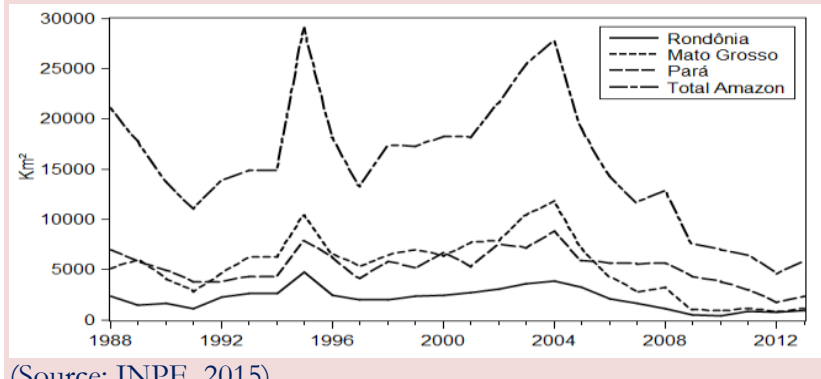

(Source: INPE, 2015)

On December 21, 2007, a legal framework was established to combat illegal deforestation in the Amazon through Decree 6321. Thereafter, the Brazilian government developed its form of legal action in the region to combat deforestation directly through command and control actions, with more intensity in the focus areas. Thus, a list of priority municipalities to combat deforestation was created, and since then, new municipalities have been included if their deforestation rates rise. On the other hand, those municipalities that have reduced their deforestation rates continue to be monitored as a precautionary measure to prevent them from slipping back to previous rates. The output of the list of priority municipalities shows the effectiveness of public policies on regulation and supervision in the region and demonstrates that the enforcement capacity of the government has been paying off practically.

In order to measure this government action on deforestation, we estimate through ordinary least squares (OLS) (Table 1) the relationship between the annual changes in deforestation as a function of the variation of the main agricultural activities identified in deforestation. In addition, two variables were included as a qualitative response. Variable $D_{d}$ represents municipalities with significantly above-average deforestation figures, and thus, represent the group of focus for deforestation in the region. $D_{p}$ represents those municipalities subsequently included in the list of priority municipalities for deforestation, reflecting policy public vigilance and control.

Table 1: OLS estimation for deforestation causes in the Brazilian Amazon for 335 municipalities

Dependent: $\Delta$ Deforestation

\begin{tabular}{lll} 
& Coefficient & Std.Error \\
\hline$\Delta$ Soybean & $0.8239^{* *}$ & 0.2842 \\
$\Delta$ Other Crops & $0.1745 \dagger$ & 0.1436 \\
$\Delta$ Cattle Ranching & $0.5755^{* *}$ & 0.1197 \\
$\Delta$ Cattle Ranching $_{t-1}$ & $0.5987^{* *}$ & 0.1279 \\
$\Delta$ GDP per capita & $0.8633^{*}$ & 0.4155 \\
$\Delta$ GDP per capita \\
$D_{d}$ & $-0.0036^{*}$ & 0.0016 \\
$D_{p}$ & $209.3530^{* *}$ & 16.4968 \\
R-squared & $-33.8904 * *$ & 9.9568 \\
Observations (cross-sections) & 0.3533 & \\
\hline
\end{tabular}

Notes: Model estimated with OLS and robust standard errors. ** and $*$ denote significance at $1 \%$ and $5 \%$ levels, respectively. $\dagger$ denotes not significant.

As expected, the coefficients for soybeans and cattle were positive, confirming the results of other researchers, as these two activities are the main precursors to deforestation in the Brazilian Amazon in the $21^{\text {st }}$ century. 
More specifically, the elasticity for cattle ranching was $26.9 \%$ and for soybean was $2.47 \%$. In 2000, Brazil had approximately 169.88 million cattle, growing to 211.28 million in 2012, an increase of nearly $25 \%$ (FAO, 2018).Most of this growth occurred in the Brazilian Amazon, mainly in the states of Para and Mato Grosso.

It is noteworthy here that cattle ranchingremains the dominant activity causing deforestation in the Amazon. Fearnside (FEARNSIDE, 2002)posits that subsidizing the intensification of livestock is not an effective strategy, as it results strongly in reinvestment in the land for its own expansion, leading to new deforestation for pasture. Thus, command and control policies are the main instrument to combat deforestation caused by these activities. It is also observed that the lagged variable for cattle ranching was significant and positive, reflecting that this activity can continue to produce impacts over time. This is a possible topic for further study.

Soybean cultivation is a highly mechanized activity that requires large amounts of capital, and developed markets and logistical conditions. Thus, it increases in areas that offer these conditions (ANDERSEN et al., 2002). Such conditions are found in the Cerrado of the Brazilian midwest, especially in Mato Grosso. Soybean production in Brazil increased from 32.7 million tons in 2000 to 81.7 million in 2013, an increase of almost $150 \%$ (FAO, 2018). Nevertheless, the expansion of soybean production in the Brazilian Amazon is not consolidated because existing infrastructure is insufficient and it has not been as major a threat compared to cattle ranching. However, there are environmental concerns about future soybean cultivation due to the expansion of global demand and its effect on planted area.

Whereas most soybeans are produced in the Mato Grosso Cerrado, the next "frontier" would be the Amazon, although the region does not present a propitious climate and soil conditions for its cultivation and it does not have an established market to make production viable(CAMPOS, 2012). Another cause of deforestation in the Amazon that is associated with agriculture is the slash-and-burn method for clearing areas to be cultivated, which releases nutrients into the soil (FEARNSIDE, 1989).

The result for the variable other crops proved positive, although the variable was not statistically significant for deforestation. Agriculture is developed by replacing native forests, mainly for monoculture. In the case of soybean-producing regions, a second annual crop (called Safrinha), such as corn, is cultivated on most land. This use of the same area does not require new deforestation but contributes to the productive use of the land and increased agricultural production.

The positive coefficient for GDP per capita confirms the expected result, showing that income increases with the expansion of activities in the region. Then, the predominance of agriculture and cattle ranching in the region eventually leads to even more use of natural resources. However, the negative coefficient for GDP per capita square shows that income has higher decreasing scale effects on the variation of deforestation. As income increases, so does the level of information and social organization conducted, suggesting that there is a reflex response to growing awareness about the importance of preserving the Amazon. Dietz and Adger (2003)note that government policies dealing with environmental problems tend to expand as the country develops economically.

Variable $D_{d}$ was found to be positive and significant. This variable represents a group of 19 municipalities with very high annual deforestation rates compared to other municipalities in the same period. The relevance of this small group of municipalities in deforestation is evident by analyzing their agricultural pro- 
duction and deforestation rates. These 19 municipalities together accounted for 37.5\% $\left(51,335.5 \mathrm{~km}^{2}\right)$ of the increased deforested area in the three selected states for the period between 2001 and 2012, 29.7\% of the cattle herd variation, and $14.5 \%$ of the soybeanplanted area. The correlation between deforested area and cattle herd variation is high and positive (0.861). Thus, anti-deforestation policies should be implemented more incisively in these places in order to constrain illegal activities and agents, and inhibit or substantially reduce deforestation.

It is clear that the protection of the Amazon rainforest depends on both economic agents and government guidance. Concerning the market, consumers may demand certification of agricultural production originating in the Amazon, ensuring that production has not resulted in new deforestation(MILDER et al., 2015). In addition, producers need to develop strategies to increase productivity in areas already occupied. Government oversight should guide agriculture and cattle ranching, which are the main cause of deforestation, so that these activities reduce their impacts in the Amazon. The government could also develop financial and tax policies as incentives for economic agents who already comply with current legislation, stimulating others to start complying. Activities that do not have risk of deforestation could be stimulated, thereby combining economic alternatives with the preservation of environment (CHOMITZ, 2004; GODAR; TIZADO; POKORNY, 2012; HUMPHRIES et al., 2012).

The focus of this study was to consider the effects of public policies and actions to combat deforestation. The variable $D_{p}$ was employed to represent the Brazilian government's actions to combat deforestation on priority municipalities. As expected, the coefficient was negative and statistically significant, demonstrating that government enforcement policies result in reduced deforesta- tion, although in a limited way. In addition, Arima et al. (2014) found the effect of public policies to be significant when analyzing it separately from other variables in their model. Individual knowledge of the rules for using and exploiting native forest by economic agents in the Amazon is necessary, and the perceptions of landowner about the possibility of being inspected and fined for violating the law could assist in combating illegal deforestation (SCHMIDT; MCDERMOTT, 2014). Table 2 shows the comparative results of the first and second models.

Table 2: OLS estimation for deforestation causes in the Brazilian Amazon with selected municipalities

Dependent: $\Delta$ Deforestation

$\Delta$ Deforestation

$>10 \mathrm{~km}^{2} /$ year

Coeffi-

Std.Error

cient

\begin{tabular}{lll}
\hline$\Delta$ Soybean & $0.9879 * *$ & 0.4177 \\
$\Delta$ Other Crops & $0.0772 \dagger$ & 0.1782 \\
$\Delta$ Cattle Ranching & $0.6476^{* *}$ & 0.1406 \\
$\Delta$ Cattle Ranching $t-1$ & $0.6777^{* *}$ & 0.1486 \\
$\Delta$ GDP per capita & $1.6232^{*}$ & 0.7438 \\
$\Delta$ GDP per capita ${ }^{2}$ & $-0.0066 *$ & 0.0029 \\
$D_{d}$ & 204.3758 & \\
$D_{p}$ & $* *$ & 16.5325 \\
R-squared & -35.4338 & \\
Observations & $* *$ & 10.0896 \\
sections) & 0.2709 & \\
\hline Noss- & 1680 & \\
\hline
\end{tabular}

Notes: Model estimated with OLS and robust standard errors. $* *$ and $*$ denote significance at $1 \%$ and $5 \%$ levels, respectively. $\dagger$ denotes not significant.

Comparing the two models, the coefficients did not change significantly. It is noteworthy that soybeans, cattle herds, and per capita GDP showed positive and significant coefficients, with elasticity of $2.4 \%$ for the soybean production and $9.05 \%$ for cattle herds. This small difference between the two models confirms that these activities continue to be the main cause of deforestation, but are concentrated in a particular region in the Brazilian Amazon. These 168 municipalities accounted for $95.6 \%$ of the total deforestation variation, $77.5 \%$ of the soybean planted area, 
and $83 \%$ of the livestock of the 335 municipalities selected, which demonstrates a spatial concentration of both activities as well as deforestation.

For the locations where agricultural activities are relevant, the Brazilian government could define more precisely its enforcement strategies in order to act precisely in areas of expansion by reducing pressure for further expansion in the Amazon and promoting illegal deforestation. Institutional mechanisms to combat deforestation must be enhanced to prevent areas of native forest from being destroyed, but must be consistent with the economic importance of the relevant commodity. $D_{d}$ shows that deforestation is geographically concentrated, which should enable pressure groups, such as civil society, and economic actors besides the government to intensify their actions.

As the conditions for soybean cultivation are being reached by regional development, greater market integration, and expansion of infrastructure and logistics investment, the dragging effect tends to move cattle ranching to new areas in the Amazon (FEARNSIDE, 2001). Soybean, being one of Brazil's main exports, receives significant investment for logistics infrastructure. When production costs are reduced by this improvement in the means of transport, it creates a favorable environment for the expansion of soybean cultivation. The Amazon is threatened by the trend of expanding the transportation network from the Cerrado to the north of Brazil.

Again, we find that the coefficient for the variable $D_{p}$ was negative, which reinforces the hypothesis that the mechanisms of command and control of the Brazilian government in the Amazon, when applied in specific locations, resulted insuccessful reduction of annual deforestation rates. Analyzing all deforestation for Mato Grosso, Para, and Rondônia, during 1988-2007, the average annual deforestation was $14,726.8$ square kilometers per year, while for 2008-2013, the average rate dropped to $5,595 \mathrm{~km}^{2}$ per year.

However, it is possible that the government's ability to slow deforestation using only its enforcement capacity is reaching a limit with the stabilization of the deforestation rate, which can be observed in Figure 1 from 2008. Such exhaustion of deforestation contention from government policies and operations requires the development of new policies that go beyond the fight against illegality and constraining economic agents. It should include the formulation of legal incentive policies, which could have a significant effect on both control deforestation and the sustainable use of areas, combining production with preservation.

In this context, it is important to develop new mechanisms to reduce deforestation. Public policies can give market incentives to economic agents that comply with the legislation. For example, official rural credit, which has been an important source of agricultural resources in Brazil since 2008, funds only farmers in the Amazon Biome who do not deforest new areas after this year. With this restriction, farmers need to conserve native forest areas on their land to keep qualifying for resources, and this strategy also incentive production and preservation. Such results are amplified by the involvement of market institutions; for example, a Soy Moratorium deal has prevented agricultural companies from financing soybean producers in deforested areas since 2006. Failure to follow these rules implies producers cannot raise sufficient funds for costly production, such as soybean cultivation.

Enforcement strategies are effective to prevent deforestation when economic agents do not consider illegality to be an advantage (freerider). Weak control mechanisms provide opportunities for illegality. In other words, if agents consider that the benefits of illegality are higher than its costs (e.g., fines) they 
would continue deforestation to maximize their profits. The efficiency of the Brazilian government in reducing deforestation in the $21^{\text {st }}$ century precisely reflects the new path that economic agents have been developing, with new conservation strategies that add value to production.

\section{CONCLUSION}

The objective of this study was to investigate the relationship between deforestation in the Amazon and the expansion of agricultural activities during the $21^{\text {st }}$ century, based on the hypothesis that the government could take advantage of command and control power to enforce laws and contain deforestation. The results confirmed the hypothesis: that the government, through its policies, has been able to reduce deforestation.

The results show that although cattle ranching remains the main activity threatening the Amazon, it also has great economic importance for the region, as do soybeans. Even though cattle ranching is not a major cause of deforestation, it ultimately raises capital and moves activities to unexplored areas, thereby encouraging deforestation(FEARNSIDE, 2001). The results suggest that institutions, using market mechanisms, could contribute to combating deforestation by encouraging agents to adopt sustainable practices, answering the demands of consumers and maintaining the reputations of economic agents along supply chains (GIBBS et al., 2015).

The development of economic activities alongside conservation of native forest in the Brazilian Amazon is a challenge that persists in the $21^{\text {st }}$ century. The continuous exploitation of natural resources has mobilized civil society to press for public policies to combat illegal deforestation in the Amazon. The result has been intensification of monitoring and control operations in recent years, guided by stricter and more effective legislation to punish agents that circumvent such laws.
This study demonstrated that antideforestation policies in priority municipalities have produced significant results since their implementation, raising the risk of illegal activities. However, government enforcement, while able to reduce deforestation, is reaching its limit in producing its effects, in which the annual rate of deforestation goes to stabilize at a certain level because of its saturation. To reduce the rate of deforestation further in the region, new control mechanisms should be developed to encourage sustainable activities that meet legal requirements, thereby making illegal activities less attractive for free-riders.

It is clear that government actions are an important factor for transforming economic organization that results in deforestation. Thus, an analysis of the conditions of the sectors directly affected by state enforcement could provide valuable information on the impact of state actions on the productivity of the agricultural sector, including the timber industry.

\section{REFERENCES}

ALDRICH, S. et al. Contentious Land Change in the Amazon's Arc of Deforestation. Annals of the Association of American Geographers, v. 102, n. 1, p. 103-128, 2012. https://doi.org/10.1080/00045608.2011.620501

ANDERSEN, L. E. et al. The dynamics of deforestation and economic growth in the Brazilian Amazon. New York: Cambridge University Press, 2002.

ANDERSEN, L. E.; GRANGER, C. W. J. Modeling Amazon deforestation for policy purposes: reconciling conservation priorities and human development. Environmental Economics and Policy Studies, v. 8, n. 3, p. 201-210, 2007. https://doi.org/10.1007/BF03353957 ARAUJO, C. et al. Property rights and deforestation in the Brazilian Amazon. Ecological Economics, v. 68, n. 8-9, p. 2461-2468, 2009. https://doi.org/10.1016/j.ecole con.2008.12.015 
ARIMA, E. Y. et al. Public policies can reduce tropical deforestation: Lessons and challenges from Brazil. Land Use Policy, v. 41, p. 465473, 2014. https://doi.org/10.1016/i.landusepol.2014.06.026 CAMPOS, I. Limites e condicionantes à expansão da sojicultura na Amazônia. Novos Cadernos NAEA, v. 15, n. 2, p. 197-216, 2012. https://doi.org/10.5801/ncn.v15i2.973

CHOMITZ, K. M. Transferable development rights and forest protection: An exploratory analysis. International Regional Science Review, v. 27, n. 3, p. 348-373, 2004. https://doi.org/10.1177/0160017604266030

DIETZ, S.; ADGER, W. N. Economic growth, biodiversity loss and conservation effort. Journal of Environmental Management, v. 68, n. 1, p. 23-35, maio 2003. https://doi.org/10.1016/S0301-4797(02)00231-1

FAO. FAOSTAT. Disponível em: <http://www.fao.org/faostat/en/\#data/QL >. Acesso em: 30 abr. 2018.

FEARNSIDE, P. M. Burn quality prediction for simulation of the Agricultural System of Brazil's Transamazon Highway Colonists. Turrialba, v. 39, n. 2, p. 229-235, 1989.

FEARNSIDE, P. M. Soybean cultivation as a threat to the environment in Brazil. Environmental Conservation, v. 28, n. 1, p. 23-38, 2001. https://doi.org/10.1017/S0376892 $\underline{901000030}$

FEARNSIDE, P. M. Can pasture intensification discourage deforestation in the Amazon and Pantanal regions of Brazil? In: FLORIDA, U. P. OF (Ed.). . Deforestation and land use in the Amazon. Gainesville: University Press of Florida, 2002. p. 385.

FEARNSIDE, P. M. Deforestation in Brazilian Amazonia: History, rates, and consequences. Conservation Biology, v. 19, n. 3, p. 680-688, 2005. https://doi.org/10.1111/j. 1523-1739.2005.00697.x

GARRETT, R. D.; LAMBIN, E. F.; NAYLOR, R. L. Land institutions and supply chain configurations as determinants of soybean planted area and yields in Brazil. Land
Use Policy, v. 31, p. 385-396, mar. 2013. https://doi.org/10.1016/j.landusepol.2012.08.002 GIBBS, H. K. et al. Brazil's Soy Moratorium. Science, v. 347, n. 6220, p. 377-378, 23 jan. 2015. https://doi.org/10.1126/science.aaa0181

GODAR, J.; TIZADO, E. J.; POKORNY, B. Who is responsible for deforestation in the Amazon? A spatially explicit analysis along the Transamazon Highway in Brazil. Forest Ecology and Management, v. 267, p. 58-73, 2012. https://doi.org/10.1016/i.foreco.2011.11.046 HARGRAVE, J.; KIS-KATOS, K. Economic Causes of Deforestation in the Brazilian Amazon: A Panel Data Analysis for the 2000s. Environmental and Resource Economics, v. 54, n. 4, p. 471-494, 2013. https://doi.org/10.1007/s10640-012-9610-2

HECHT, S. B. Environment, development and politics: Capital accumulation and the livestock sector in Eastern Amazonia. World Development, v. 13, n. 6, p. 663-684, 1985. https://doi.org/10.1016/0305-750X(85)90114-7

HIROTA, M. et al. Global Resilience of Tropical Forest and Savanna to Critical Transitions. Science , v. 334, n. 6053, p. 232235, 14 out. 2011. https://doi.org/10.1126/scien ce. 1210657

HUMPHRIES, S. et al. Are community-based forest enterprises in the tropics financially viable? Case studies from the Brazilian Amazon. Ecological Economics, v. 77, p. 62-73, maio 2012. https://doi.org/10.1016/i.eco lecon.2011.10.018

IBGE. Sistema IBGE de Recuperacao automatica-SIDRA. Disponível em: $<$ http://www.sidra.ibge.gov.br/>. Acesso em: 27 fev. 2015.

INPE. Prodes: Monitoramento da floresta Amazônica por satélite. Disponível em: $<$ www.obt.inpe.br/prodes/>. Acesso em: 27 fev. 2015.

JONES, B. D.; TRUE, J. L.; BAUMGARTNER, F. R. Does Incrementalism Stem from Political Consensus or from Institutional Gridlock? American Journal of Political Science, v. 41, n. 4, p. 1319-1339, 
1997. https://doi.org/10.2307/2960491

KIRBY, K. R. et al. The future of deforestation in the Brazilian Amazon. Futures, v. 38, p. 432-453, 2006. https://doi.org/10.1016/i.futures.2005.07.011

KUNZMANN, K. The Non-legally Binding Instrument on Sustainable Management of All Types of Forests - Towards a Legal Regime for Sustainable Forest Management? German Law Journal, v. 09, n. 08, p. 981-1006, 2008. https://doi.org/10.1017/S2071832200000250

MARGULIS, S. Causes of Deforestation of the Brazilian Amazon. Washington D.C.: [s.n.].

MEADOWS, D. . et al. The Limits to Growth. Chelsea, v. 205, p. 205, 1972.

MILDER, J. C. et al. An agenda for assessing and improving conservation impacts of sustainability standards in tropical agriculture. Conservation Biology, v. 29, n. 2, p. 309320, 2015. https://doi.org/10.1111/cobi.12411

MME. Lista de Municípios Prioritários da Amazônia. Disponível em: <http://www. mma.gov.br/florestas/controle-e-prevençãodo-desmatamento/plano-de-ação-para-ama zônia-ppcdam/lista-de-municípios-prioritári os-da-amazônia>. Acesso em: 27 fev. 2015. MORTON, D. C. et al. Cropland expansion changes deforestation dynamics in the southern Brazilian Amazon. Proceedings of the National Academy of Sciences of the USA, v. 103, n. 39, p. 14637-14641, 2006. https://doi.org/10.1073/pnas.0606377103

NEPSTAD, D. et al. Road paving, fire regime feedbacks, and the future of Amazon forests. Forest Ecology and Management, v. 154, n. 3, p. 395-407, dez. 2001. https://doi.org/10. 1016/S0378-1127(01)00511-4

NEPSTAD, D. C.; STICKLER, C. M.; ALMEIDA, O. T. Globalization of the Amazon soy and beef industries: Opportunities for conservation. Conservation Biology, v. 20, n. 6, p. 1595-1603, 2006. https://doi.org/ 10.1111/i.1523-1739.2006.00510.x

NOLTE, C. et al. Governance regime and location influence avoided deforestation success of protected areas in the Brazilian Amazon. Proceedings of the National Academy of Sciences of the United States of America, v. 110, n. 13, p. 4956-4961, 26 mar. 2013. https://doi.org/10.1073/pnas.1214786 $\underline{110}$

NORTH, D. C. Institutions, Institutional Change and Economic Performance. New York: Cambridge University Press, 1990. https://doi.org/10.1017/CBO9780511808678

NORTH, D. C. Economic Performance Through Time. The American Economic Review, v. 84, n. 3, p. 359-368, 1994.

PFAFF, A. et al. Road Investments, Spatial Intensification and Deforestation in the Brazilian Amazon. Journal of Regional Science, v. 47, n. 1, p. 109-123, 1 fev. 2007. https://doi.org/10.1111/j.1467-9787.2007.00502.x

RUDORFF, B. F. T. et al. The soy moratorium in the Amazon biome monitored by remote sensing images. Remote Sensing, v. 3, n. 1, p. 185-202, 2011. https://doi.org/10. $\underline{3390 / \mathrm{rs} 3010185}$

SCHMIDT, C. A.; MCDERMOT'T, C. L. Deforestation in the Brazilian Amazon: Local Explanations for Forestry Law Compliance. Social \& Legal Studies, v. 24, n. 1, p. 3-24, 2014. https://doi.org/10.1177/0964663914552213

SCHNEIDER, T. W. A non-legally-binding Instrument as an Alternative to a Forest Convention by. Development, 2006.

SCHWARTZMAN, S.; ZIMMERMAN, B. Conservation Alliances with Indigenous Peoples of the Amazon. Conservation Biology, v. 19, n. 3, p. 721-727, 1 jun. 2005. https://doi.org/10.1111/i.1523-1739.2005.00695.x

TUNDISI, J. G. et al. How many more dams in the Amazon? Energy Policy, v. 74, p. 703-708, nov. 2014. https://doi.org/10.1016/j. enpol.2014.07.013

UNITED NATIONS. Annex III: Non-legally binding authoritative statement of principles for a global consensus on the management, conservation and sustainable development of all types of forests. Report of the United Nations Conference on Environment and 
Development, v. III, n. June, 1992.

VERBURG, R. et al. The impact of commodity price and conservation policy scenarios on deforestation and agricultural land use in a frontier area within the Amazon. Land Use Policy, v. 37, p. 14-26, 2014. https://doi.org/10.1016/i.landusepol.2012.10.003

WALKER, R.; MORAN, E.; ANSELIN, L. Deforestation and cattle ranching in the Brazilian Amazon: External capital and household processes. World Development, v. 28, n. 4, p. 683-699, 2000. https://doi.org/10. 1016/S0305-750X(99)00149-7

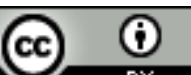

access article distributed under the terms of the Creative Commons Attribution License, which permits unrestricted use, distribution, and reproduction in any medium, provided the original work is properly cited.

Article received on July 30, 2019.

Evaluated September 02, 2019.

Accepted on September 09, 2019.

Published on October 02, 2019.

How cite this article (ABNT):

SILVA, David Costa Correia; RODRIGUES, Marcos. Federal enforcement and reduction of deforestation in the Brazilian Amazon. Estação Científica (UNIFAP), Macapá, v. 9, n. 1, p. 75-88, jan./mar. 2019. 